Agro-Science Journal of Tropical Agriculture, Food, Environment and Extension Volume 20 Number 2 (April 2021) pp. $74-80$

ISSN 1119-7455

\title{
EFFECT OF FERMENTATION MEDIA AND TIME ON PHYSICOCHEMICAL AND SENSORY PROPERTIES OF SOYBEAN POWDERS
}

\author{
${ }^{1}$ Ugwuona F.U., ${ }^{2}$ Obeta N.A., ${ }^{2}$ Asogwa I.S. and ${ }^{3}$ Sabo T.R. \\ ${ }^{1}$ Department of Food Science \& Technology, \\ Michael Okpara University of Agriculture, Umudike, Umuahia, Abia State, Nigeria \\ ${ }^{2}$ Department of Food Science \& Technology, Faculty of Agriculture, \\ University of Nigeria, Nsukka, Enugu State, Nigeria \\ ${ }^{3}$ Department of Home Science \& Management, Faculty of Agriculture, \\ Nasarawa State University, Keffi, Nigeria \\ *Corresponding author's email: nwamaka.obet@unn.edu.ng
}

\begin{abstract}
Fermentation improves quality of food, and is exploited in processing soymilk powder. Unfortunately, there is no unified fermentation procedure for producing powdered soymilk in Nigeria. A fermentation condition to produce high nutritional and most acceptable powdered soymilk is ideal for Nigerians. This study evaluated the effect fermentation media and time on physicochemical and sensory properties of powdered soymilk. Seven batches (600 $\mathrm{g}$ each) of soybean seeds were fermented, the first three in neutral water, sample A for 4 $h, B$ for $16 h$ in the same water, and $C$ for $16 h$ but changing the water every $4 h$. The next two were fermented in alkaline solution for $16 \mathrm{~h}, \mathrm{D}$ in the same water, and $E$ with changing the water every $4 \mathrm{~h}$. The last two were fermented for $16 \mathrm{~h}$ in acidic solution, Fin the same solution and $G$ with changing the water every $4 \mathrm{~h}$. The beans were processed into cooked soy flour and analyzed for physicochemical and sensory properties. Fermentation enhanced better quality than soaking; fermentation time and medium $p H$ significantly $(p<0.05)$ induced variations in quality of the powder. Soaking produced soy powder with highest carbohydrate $(44.47 \%)$ and fibre $(1.355 \%)$ but significantly $(p<0.05)$ low in protein, minerals and crude fat. Continuous 16-h fermentation in the same medium produced soy powders with lowest phytochemical contents. Soaked $(4$ h) soybean in neutral water (A) produced powder with $39.50 \%$ protein, $44.47 \%$ carbohydrates, $1.35 \%$ fibre, $5.58 \%$ fat and $2.75 \%$ ash while continuous fermentation for $16 \mathrm{~h}$ in the same water produced powder (B) with $42.47 \%$ protein, $41.71 \%$ carbohydrate, $1.22 \%$ fibre, $5.81 \%$ fat and $2.42 \%$ ash. Continuous 16-h fermentation was better than changing the medium; and neutral medium was better than acidic and alkaline medium. All the soy powder high sensory scores $(\geq 5)$ and were acceptable to the panelists. Thus, 16-h continuous fermentation in neutral medium was more cost effective and produced soybean powder of better quality than fermenting in alkaline and acidic media.
\end{abstract}

Key words: fermentation time, quality, soaking media, soybean powders

\section{INTRODUCTION}

The current global economic recession and poor income make it impossible for many families to afford animal protein. An alternative rich plant protein is usually sourced to ameliorate protein energy problems among the low-income earners. Soybean (Glycine max) is a leguminous crop. The seed flour is a good source of protein, particularly for families with low income who cannot afford animal protein. Soybeans are highly recognized globally for their high nutritional value and excellent functional properties. The seed flour is rich in most essential amino acids, particularly lysine, arginine, cysteine, leucine and methionine (Giampietrol et al., 2004), thereby making it a relatively inexpensive source of protein. Soybean flour is also rich in minerals, especially calcium, potassium, magnesium, iron, zinc and copper (FAO, 2009). It is also an excellence source of vitamins including thiamine, riboflavin and niacin (Singh et al., 2000). Soy flour is a good source of protein, essential fatty acids, dietary fiber and many important bioactive compounds such as is flavones. Important bioactive compounds found naturally in soy flour have been proven to relieve menopausal symptoms such as hot flashes, maintain healthy bones and prevent prostate, breast and colorectal cancers (Ugwuona, 2009). The content and profile of these food nutrients and bioactive compounds vary depending on soybean varieties and processing methods employed (Prestamo et al., 2000). Soy foods are healthy because of the high quantity of protein and these bioactive ingredients in them (Sneller, 2003). 
Globally, there is increasing awareness of the potential value of soybean flour as a relatively cheap source of protein in the diet. Incorporation of soybean flour into locally produced weaning and adult foods is used to combat protein-energy malnutrition among the low-income families.

Unfortunately, soybean has many antinutritional factors, including phytates, tannins, polyphenols, trypsin inhibitors and many oligosaccharides, notably raffinose and starchyose (Prodanov et al., 2004), which have to be removed before its nutrient potentials could be fully harnessed. Most vital metallic minerals are bound with phytates, making them not releasable to the human enzymes for digestion and utilization. Thus, raw soybeans need to be properly processed to reduce many of these anti-nutritional factors, improve taste and texture of soy flour, making it more acceptable to consumers before consumption. Processing also improves functional properties of soybean powder for more technological application.

Soaking, boiling and fermentation are common processing methods used in producing soybean flours, but these methods have their limitations. Soaking breaks down many anti-nutritional factors such as protease inhibitor, phytic acid and $\alpha$ galactoside linkages due to partial or total solublization and removal (Prodanov et al., 2004). Extended soaking in tropical climates can lead to undesirable microbial deterioration while cooking for a long time is time- and energy-consuming and cost-ineffective. Also, soaking for too long can cause loss of many essential water-soluble vitamins and minerals (Akande and Fabiyi, 2010). Fortunately, soaking in alkaline solution (e.g., sodium bicarbonate solution) has been shown to reduce cooking time for a number of legumes (Singh et al., 2000).

There is currently no standardized soaking time, $\mathrm{pH}$ and fermentation period to achieve high quality soy flour. It is therefore the thrust of this study to investigate the effect of soaking time, $\mathrm{pH}$, changing of water during soaking and fermentation on quality characteristics of soy flour.

\section{MATERIALS AND METHODS \\ Materials}

Soybean (Glycine max) seeds and food grade chemicals (citric acid and Sodium bicarbonate) were purchased from retail stocker at Lafia modem market in Lafia, Nasarawa State, Nigeria. All reagents used for analysis were of analytical quality and were purchased from a registered Chemical agent, Lavans Nig. Ltd, Nsukka, Enugu State.

\section{Processing of Soybean Flours}

Alkaline, neutral and acidic media were used for soaking and fermentation of soybean seeds. Potable water served as the neutral media. The acidic solution was prepared by dissolving $40 \mathrm{~g}$ of citric acid in $4 \mathrm{~L}$ of distilled water (1\% citric acid) while the alkaline solution was by dissolving $25 \mathrm{~g}$ of $\mathrm{NaHCO}_{3}$ in $5 \mathrm{~L}$ of distilled water $\left(0.5 \% \mathrm{NaHCO}_{3}\right)$.

Soybean seeds were cleaned and divided into seven batches of $600 \mathrm{~g}$ each. First batch (A) was soaked in $2 \mathrm{~L}$ of potable water for $4 \mathrm{~h}$ to aid dehulling. The second (B) and third (C) batches were each fermented in $2 \mathrm{~L}$ of potable water for $16 \mathrm{~h}$ but with water content of $\mathrm{C}$ being changed every 4-h intervals. The fourth (D) and fifth (E) batches were each fermented in $2 \mathrm{~L}$ of alkaline $\left(0.5 \% \mathrm{NaHCO}_{3}\right)$ solution for $16 \mathrm{~h}$ and with the water content of $\mathrm{E}$ being changed at $4-\mathrm{h}$ intervals. The sixth $(\mathrm{F})$ and seventh $(\mathrm{G})$ batches were fermented in $2 \mathrm{~L}$ of $1 \%$ citric acid solution for $16 \mathrm{~h}$ but with the water content of $\mathrm{G}$ being changed at 4-h intervals.

After soaking and fermentation, seeds were dehulled manually, washed severally with clean potable water and the dehulled seeds (nibs) cooked in boiling water for $30 \mathrm{~min}$. The cooked nibs were drained, allowed to cool, sun-dried (48 h) and then oven-dried $\left(48 \mathrm{~h}, 55^{\circ} \mathrm{C}\right)$. The dried nibs were milled in to powder with attrition mill (model GX 160). The powder was sieved through $0.20 \mathrm{~mm}$ pore sieve to remove fibrous materials, re-milled, packed in polyethene bags and placed in airtight plastic container. The containers were stored in the laboratory cupboard and analyzed for physicochemical and sensory properties within three days.

\section{Determination of Nutrient Composition of the Soybean Powders}

Moisture, crude protein $(\% \mathrm{~N} \times 6.25)$, fat, fibre and ash contents of the soy flours were determined in triplicates using standard procedures of the Association of Official Analytical Chemist (AOAC, 2000). The moisture content was calculated as loss in weight of soy flour after drying at $105^{\circ} \mathrm{C}$ for $4 \mathrm{~h}$ in hot air oven; and crude protein $(\mathrm{N} \times 6.25)$ content was estimated after digestion with concentrated $\mathrm{H}_{2} \mathrm{SO}_{4}$ in Micro Kjedhal unit.

Total lipid (fat) was estimated by exhaustive extraction of a sub sample $(5 \mathrm{~g})$ of each soy flour with petroleum ether (boiling point: $40-60^{\circ} \mathrm{C}$ ) using a Soxhlet apparatus. Digestible carbohydrate (excluding fibre) was determined by difference.

The residual weights after incinerating $5 \mathrm{~g}$ of each of the dry soy flours at $600^{\circ} \mathrm{C}$ for $2 \mathrm{~h}$ in a muffle furnace were the ash contents and were expressed as percentage of the original weights of samples. Each of the ash samples was dissolved in $2 \mathrm{ml}$ of concentrated hydrochloric acid $(\mathrm{HCl})$, filtered and then washed with deionized water through Whatman no. 540 filter papers into dilution tubes. These were made up to $25 \mathrm{ml}$ marks with deionized water prior to mineral analysis (AOAC, 2000). The filtrates were used to determine calcium $(\mathrm{Ca})$, sodium $(\mathrm{Na})$, Iron $(\mathrm{Fe})$, Magnesium $(\mathrm{Mg})$ and potassium (K) contents of the samples, using atomic absorption spectrophotometer (ASS) (A. 
Analyst 300, Perkin Elmer, Morwalk, Conn, U.S.A). Phosphorus was determined using the Vanadomolybdate method (AOAC, 2000).

\section{Determination of Phytochemical Constituents Determination of B-carotene contents}

Soy flour $(1 \mathrm{~g})$ was dissolved in $10 \mathrm{ml}$ of acetone in $30 \mathrm{ml}$ conical flask and swirled for about $2 \mathrm{~min}$. This was allowed to stand for $30 \mathrm{~min}$ with repeated shaking at $5 \mathrm{~min}$. intervals to extract the $\beta$-carotene in the sample. This was rested for $5 \mathrm{~min}$, and the upper layer decanted into a test tube. Five $\mathrm{ml}$ of benzene was added and the mixture shaken gently and allowed to rest for $2 \mathrm{~min}$. Two distinct layers were observed, and the upper layer was obtained using a separating funnel. This was used to determine total $\beta$-carotene content in the samples (Singleton et al., 1999). Absorbance was read using spectrophotometer (Spectronic 21 days, Multon Roy, Rochester Ny, U.S.A.) at $453 \mathrm{~nm}$, and $\beta$ carotene content calculated as follow:

$$
\left(\text { Abs x } 10 \times 1 / 510^{4}\right) / 3370 \text {. }
$$

\section{Determination of total phenol}

Total phenol content was determined using Folinciocalteau method (Roesler et al., 2006). To do this, the various soy flours, $0.5 \mathrm{ml}$ aliquot of freshly prepared extracts (from $1 \mathrm{~g}$ of flour in $25 \mathrm{ml}$ of distilled water) was mixed with equal volume of water, $0.5 \mathrm{ml}$ Folin-Ciocalteu's reagent and $2.5 \mathrm{ml}$ of saturated solution of sodium carbonate $\left(\mathrm{Na}_{2} \mathrm{CO}_{3}\right)$. The mixture was centrifuged (3000rpm, $20 \mathrm{~min}$ ) (Beckman coulter Ltd Palo, Alto, Calitonia, U.S.A) and absorbance of supernatant measured after 40 $\min$ at $725 \mathrm{~nm}$. Garlic acid was prepared at concentrations of $0.0,3.0,6.0,12.0,18.0,24.0$ and $30.0 \mu \mathrm{g} \mathrm{ml}^{-1}$ to plot total phenol standard curve. Total phenol content was extrapolated from the standard curve using the absorbance values and expressed as garlic acid equivalents (GAE $100 \mathrm{~g}^{-1}$ ).

\section{Determination of tannin content}

The condensed tannin content of the soy flours was determined by the method of Price and Butler (1977). The soy flour samples (1 g) were added to $10 \mathrm{ml}$ of distilled water, and mixed with $0.5 \mathrm{ml}$ of $0.1 \mathrm{M} \mathrm{FeCl}_{3}$ in $0.1 \mathrm{NHCl}$ and $0.5 \mathrm{ml}$ of 0.008 $\mathrm{MK}_{3} \mathrm{Fe}(\mathrm{CN})_{6}$. The mixture was allowed to stand for $1 \mathrm{~min}$., and absorbance was read at $720 \mathrm{~nm}$. Tannin content was extrapolated from a standard curve (prepared with tannic acid at concentrations of 0.0 , 0.01, 0.04, 0.08, 0.15, 0.20, 0.50 and $\left.1.0 \mathrm{mg} \mathrm{m}^{-1}\right)$ and expressed as tannic acid equivalents (TAE $100 \mathrm{~g}^{-1}$ ).

\section{Determination of phytate content}

Phytate content was determined using the method of AOAC (2000). The soy flour samples $(4.0 \mathrm{~g})$ were soaked in $100 \mathrm{ml}$ of $0.2 \mathrm{~N}$ hydrochloric acid ( $\mathrm{HCl})$ solution for $3 \mathrm{~h}$ and then filtered through Whatman N0. 2 filter paper. The filtrates $(25 \mathrm{ml})$ were pipetted into $50 \mathrm{ml}$ conical flasks, and $5 \mathrm{ml}$ of $0.3 \%$ ammonium thiocyanate solution added, after which $53.5 \mathrm{ml}$ of distilled water was added and the mixtures were titrated against standard Iron (III) chloride solution containing $0.00195 \mathrm{~g} \mathrm{Fe}^{3+} \mathrm{ml}^{-1}$ until a brownish yellow colour persisted for $5 \mathrm{~min}$. The phytate content of the flours was calculated from the titre value and expressed as percentage phytate.

\section{Functional Properties Water absorption capacity}

Water absorption capacity of the soy flour samples was determined using the method of Abbey and Ibe (1988) with slight modification. One gram of each of the flour samples was mixed with $10 \mathrm{ml}$ of distilled water in a centrifuge tube. The suspension was agitated for one hour on a griffin flask shaker after which it was centrifuged for $15 \mathrm{~min}$ at 2200 $\mathrm{rpm}$. The volume of water or oil on the sediment water was measured. Water and oil absorption capacities were calculated as $\mathrm{ml}$ of water or oil absorbed per gram of flour respectively.

\section{Least gelation concentration}

Least gelation concentrations for the various flour samples were determined using the method of Abbey and Ibeh (1988). Each flour sample was mixed at eight different concentrations of 2, 4, 6, 8, $10,12,16$ and $20 \mathrm{~g}$ per $100 \mathrm{ml}$ of distilled water in separate test tubes. This gave a total of 56 test tubes of flour suspensions. The test tubes were heated for $1 \mathrm{~h}$ in a boiling water bath (Beckman coulter Ltd Palo, Alto, Calitonia, U.S.A), cooled rapidly under running tap water and further cooled for $2 \mathrm{~h}$ in a refrigerator at $4^{\circ} \mathrm{C}$. The least gelation concentration was regarded as that concentration at which the sample from the inverted test tube did not fall or slip.

\section{Viscosity analysis}

Apparent viscosities were determined at $8^{\circ} \mathrm{C}$ using a Brookfield DVII+Viscometer (Brookfield Engineering Laboratory Incorporation., Stoughton, Mass., U.S.A.). A $10 \%$ soy flour suspension in distilled water was prepared at room temperature $\left(26 \pm 2^{\circ} \mathrm{C}\right)$ and stirred mechanically for $2 \mathrm{~h}$ using a mechanical stirrer. This was cooled to $8^{\circ} \mathrm{C}$, transferred into the viscometer tube and the apparent viscometer determined. Three readings were taken per replication, and two replications were conducted.

\section{Sensory Analysis}

Trained panellists (15) of ages 17-27 years, comprising 9 females and 6 males were drawn from 21 volunteers from the staff and students of Faculty of Agriculture, Lafia, Nasarawa State University, Lafia, Nigeria. Prior to the selection, volunteers were interviewed to assess their familiarity with soy products, and how often they consume these products. The best 15 who proved familiarity with soy products were selected and trained according to the spectrum methodology of 
Mellgaard et al. (1991). Predetermined sensory attributes of soy flour were used for them to become familiar with definitions and references to these when tested. Each sample was rated on perceived intensities of standard sensory attributes (acceptability, mouth-feel, flavour, texture and colour) using a 9-point Hedonic scale with $1=$ disliked extremely, 2 = disliked very much, $3=$ disliked moderately, $4=$ disliked slightly, $5=$ neither liked nor disliked, $6=$ liked slightly, $7=$ liked moderately, $8=$ liked very much and $9=$ liked extremely. Scores were collated and analysed.

\section{Statistical Analysis}

Data generated from the study were analyzed using analysis of variance while means with significant $(p \leq 0.05)$ difference were separated with Fisher's least significant difference (LSD) using Statistical Package for Social Sciences (SPSS) version 13.0.

\section{RESULTS AND DISCUSSION}

Effect of Fermentation Time and Soaking Mediums on Proximate Composition of Soybean Powders

Table 1 shows the proximate composition of soy powders produced from soybeans fermented in different media at different time intervals. The moisture content (\%) of the flours ranged from 5.59 in $\mathrm{D}$ to 7.72 in $\mathrm{F}$. Both fermentation and $\mathrm{pH}$ of the media significantly $(p<0.05)$ influenced moisture, protein, carbohydrate, ash and fat contents of the soy powders. Also, changing the water at $4 \mathrm{~h}$ intervals during $16 \mathrm{~h}$ fermentation influenced the moisture contents of the soy powders. Soybean powders sample fermented in alkaline $\mathrm{pH}$ had significantly $(p<0.05)$ higher moisture content (Sample F with moisture content of $7.72 \%$ ) than every other sample. At $16 \mathrm{~h}$ fermentation, sample B from neutral medium had $6.45 \%$ moisture, $\mathrm{C}$ from alkaline medium had $6.85 \%$ and $\mathrm{D}$ from acidic medium had $5.59 \%$ moisture. Moisture contents of these soy flours were below the maximum 14.5\% for safe storage of food at ambient condition in the tropics. This shows that moisture content is an indicator of storability of food at ambient condition because moisture content greater than $14.5 \%$ supports microbial growth and enhances spoilage (AACC, 2000). Fermentation increased protein content from $39.50 \%$ in the unfermented sample (A) to highest value of $47.55 \%$ in the sample (F) fermented in alkaline medium for $16 \mathrm{~h}$ with changing of water at $4 \mathrm{~h}$ intervals. However, protein content of the sample fermented in the same alkaline medium without changing the water for $16 \mathrm{~h}$ decreased from $39.50 \%$ to $39.06 \%$. On the other hand, when the beans was fermented for $16 \mathrm{~h}$ without changing the water, protein content increased from $39.50 \%$ to $42.47 \%$ in neutral medium but when fermented for $16 \mathrm{~h}$ with changing of water at $4 \mathrm{~h}$ intervals (sample $\mathrm{E}$ ), the protein content was $40.63 \%$. Thus, changing water at time intervals during fermentation decreased protein content of soybean in both neutral and alkaline media. The same trend was observed when fermenting in acidic medium. Protein content increased from $39.49 \%$ in the unfermented sample to $47.29 \%$ when fermenting without changing the water but this value decreased down to $44.00 \%$ when fermenting and changing the water at $4 \mathrm{~h}$ intervals. This implies that changing the water medium at time intervals during fermentation aids leaching out of water-soluble part of the protein from the soybean.

\section{Effect of Fermentation Time and Soaking Media} on Mineral Composition of Soybean Powder

Table 2 shows the mineral composition of soy powder produced from soybean seeds subjected to fermentation conditions. Both fermentation time and the fermenting medium jointly affected mineral contents of the soy powders. Fermentation generally improved iron $\left(1.49 \mathrm{mg} 100 \mathrm{~g}^{-1}\right.$ in $\mathrm{F}$ to $5.09 \mathrm{mg} 100 \mathrm{~g}^{-1}$ in $\left.\mathrm{G}\right)$ and phosphorus (10.21 mg $100 \mathrm{~g}^{-1}$ in $\mathrm{C}$ to $16.32 \mathrm{mg} 100 \mathrm{~g}^{-1}$ in G) contents as

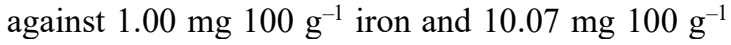
phosphorus in the unfermented sample (sample A). Iron is an important constituent of haemoglobin found in the blood. De Villota et al. (1981) emphasized the importance of iron in oxygen carriage in blood. According to National Academy of Science (2004) the recommended daily allowance of iron is between 8 to $18 \mathrm{mg} \mathrm{day}^{-1}$.

Soy powder produced from $16 \mathrm{~h}$ fermentation in neutral medium (sample B) had the highest calcium (440.44 mg 100- $\mathrm{g}^{-1}$ ) and magnesium (3.76 mg $\left.100-\mathrm{g}^{-1}\right)$ contents among all the samples. The different fermenting media and processes improved some mineral and decreased others in the flour samples as compared with the unfermented control (sample A) sample. Soy flour from $16 \mathrm{~h}$ fermentation in neutral medium (sample B) had the highest contents of calcium (440.44 mg $100-\mathrm{g}^{-1}$ ) and magnesium $\left(3.76 \mathrm{mg} 100-\mathrm{g}^{-1}\right)$ while soy powder from $16 \mathrm{~h}$ fermentation in acidic medium $(\mathrm{G})$ with changing of solution at $4 \mathrm{~h}$ intervals had the highest contents of iron (5.09 mg $100-\mathrm{g}^{-1}$ ), phosphorus $\left(16.32 \mathrm{mg} 100-\mathrm{g}^{-1}\right)$ and potassium $(41.95 \mathrm{mg} 100-$ $\left.\mathrm{g}^{-1}\right)$. However, soy powder from $16 \mathrm{~h}$ fermentation in alkaline medium (sample $\mathrm{C}$ ) without changing of water had the highest content of sodium $(1.53 \mathrm{mg}$ $\left.100-\mathrm{g}^{-1}\right)$. The relative significantly $(p<0.05)$ highest contents of iron and phosphorus in sample $\mathrm{G}$ suggests acidic solution as the best fermenting medium for hydrolysing iron from phytates and phytic acid which are highly present in soybeans.

The mineral contents in the fermented samples were at variance when compared with those in the unfermented control sample (A). The mineral contents of the powders produced from different fermenting mediums varied significantly $(p<0.05)$. The powders were rich in calcium (220.43 in $\mathrm{C}$ to $440.44 \mathrm{mg} 100-\mathrm{g}^{-1}$ in $\mathrm{B}$ ), potassium (33.33 in $\mathrm{C}$ to $41.95 \mathrm{mg} 100-\mathrm{g}^{-1}$ in $\mathrm{G}$ ) and phosphorus (6.86 in $\mathrm{F}$ to $16.32 \mathrm{mg} 100-\mathrm{g}^{-1}$ in G) contents but relatively low in sodium (1.04 in E to $1.53 \mathrm{mg} 100-\mathrm{g}^{-1}$ in C) contents. 
Table 1: Proximate composition of the soybean powders

\begin{tabular}{lcccccc}
\hline Samples & Moisture (\%) & Protein (\%) & Carbohydrates (\%) & Crude fibre (\%) & Fat (\%) \\
\hline A & $6.36^{\mathrm{e}} \pm 0.51$ & $39.50^{\mathrm{f}} \pm 0.22$ & $44.47^{\mathrm{a}} \pm 0.71$ & $1.35^{\mathrm{a}} \pm 0.01$ & $5.58^{\mathrm{d}} \pm 0.01$ & $2.75^{\mathrm{a}} \pm 0.06$ \\
B & $6.45^{\mathrm{d}} \pm 0.44$ & $42.47^{\mathrm{d}} \pm 0.14$ & $41.71^{\mathrm{d}} \pm 0.42$ & $1.22^{\mathrm{d}} \pm 0.01$ & $5.81^{\mathrm{a}} \pm 0.01$ & $2.42^{\mathrm{f}} \pm 0.05$ \\
C & $6.85^{\mathrm{b}} \pm 0.52$ & $39.06^{\mathrm{g}} \pm 0.18$ & $44.08^{\mathrm{b}} \pm 0.44$ & $1.14^{\mathrm{e}} \pm 0.14$ & $5.25^{\mathrm{f}} \pm 0.02$ \\
D & $5.59^{\mathrm{g}} \pm 0.34$ & $47.29^{\mathrm{b}} \pm 0.21$ & $37.16^{\mathrm{f}} \pm 0.38$ & $1.35^{\mathrm{a}} \pm 0.03$ & $5.62^{\mathrm{c}} \pm 0.00$ & $2.63^{\mathrm{b}} \pm 0.03$ \\
E & $6.47^{\mathrm{c}} \pm 0.44$ & $40.63^{\mathrm{e}} \pm 0.36$ & $43.34^{\mathrm{c}} \pm 0.22$ & $1.32^{\mathrm{b}} \pm 0.00$ & $5.65^{\mathrm{b}} \pm 0.03$ & $2.60^{\mathrm{c}} \pm 0.04$ \\
F & $7.72^{\mathrm{a}} \pm 0.17$ & $47.55^{\mathrm{a}} \pm 0.16$ & $35.42^{\mathrm{a}} \pm 0.11$ & $1.27^{\mathrm{c}} \pm 0.01$ & $5.45^{\mathrm{e}} \pm 0.04$ & $2.60^{\mathrm{c}} \pm 0.02$ \\
G & $6.16^{\mathrm{f}} \pm 0.13$ & $44.00^{\mathrm{c}} \pm 0.11$ & $41.29^{\mathrm{e}} \pm 0.25$ & $1.27^{\mathrm{c}} \pm 0.01$ & $4.89^{\mathrm{g}} \pm 0.01$ & $2.44^{\mathrm{e}} \pm 0.01$ \\
SEM & 0.038 & 0.001 & 0.005 & 0.002 & 0.002 & 0.034 \\
\hline
\end{tabular}

Values are means of 3 determinations. Means on the same column with different superscripts differed significantly $(p<0.05)$. A - soy powder from soybean soaked for $4 \mathrm{~h}$ in neutral water; B, C and D - soy powders from soybean fermented $16 \mathrm{~h}$, respectively in the same neutral, alkaline and acidic water; E, F and G - soy powders from soybean fermented $16 \mathrm{~h}$, respectively in neutral, alkaline and acidic water with changing water at $4 \mathrm{~h}$ intervals

Table 2: Mineral composition of the soybean powders

\begin{tabular}{|c|c|c|c|c|c|c|}
\hline Samples & 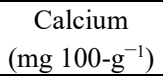 & 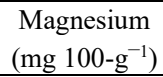 & 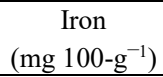 & 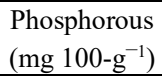 & 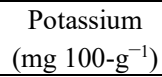 & 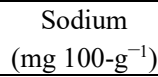 \\
\hline $\mathrm{A}$ & $420.43^{b} \pm 1.77$ & $3.24^{\mathrm{d}} \pm 0.00$ & $1.00^{\mathrm{g}} \pm 0.01$ & $10.07^{\mathrm{f}} \pm 0.01$ & $41.56^{\mathrm{c}} \pm 1.32$ & $1.40^{\mathrm{e}} \pm 0.00$ \\
\hline B & $440.44^{\mathrm{a}} \pm 1.01$ & $3.76^{\mathrm{a}} \pm 0.03$ & $2.23^{\mathrm{e}} \pm 0.01$ & $12.20^{\mathrm{b}} \pm 0.01$ & $35.67^{\mathrm{d}} \pm 1.51$ & $1.42^{\mathrm{d}} \pm 0.02$ \\
\hline $\mathrm{C}$ & $220.43^{\mathrm{g}} \pm 1.09$ & $2.64^{\mathrm{f}} \pm 0.00$ & $2.34^{\mathrm{d}} \pm 0.02$ & $10.21^{\mathrm{e}} \pm 0.00$ & $33.33^{\mathrm{g}} \pm 1.22$ & $1.53^{\mathrm{a}} \pm 0.01$ \\
\hline $\mathrm{D}$ & $306.38^{\mathrm{d}} \pm 2.01$ & $2.76^{\mathrm{e}} \pm 0.00 .2$ & $3.62^{\mathrm{b}} \pm 0.02$ & $11.74^{\mathrm{c}} \pm 0.03$ & $35.34^{\mathrm{e}} \pm 2.00$ & $1.45^{\mathrm{b}} \pm 0.01$ \\
\hline $\mathrm{E}$ & $281.37^{\mathrm{f}} \pm 1.23$ & $3.61^{\mathrm{c}} \pm 0.03$ & $2.88^{c} \pm 0.01$ & $11.44^{\mathrm{d}} \pm 0.11$ & $43.24^{\mathrm{a}} \pm 1.01$ & $1.04^{\mathrm{g}} \pm 0.00$ \\
\hline $\mathrm{F}$ & $301.28^{\mathrm{e}} \pm 1.22$ & $3.72^{\mathrm{b}} \pm 0.01$ & $1.49^{\mathrm{f}} \pm 0.00$ & $6.86^{g} \pm 0.21$ & $33.99^{f} \pm 2.00$ & $1.44^{\mathrm{c}} \pm 0.12$ \\
\hline $\mathrm{G}$ & $410.23^{\mathrm{c}} \pm 2.01$ & $2.64^{\mathrm{f}} \pm 0.02$ & $5.09^{\mathrm{a}} \pm 0.01$ & $16.32^{\mathrm{a}} \pm 0.09$ & $41.95^{b} \pm 1.32$ & $1.37^{\mathrm{f}} \pm 0.13$ \\
\hline SEM & 0.003 & 0.002 & 0.002 & 0.002 & 0.002 & 0.002 \\
\hline
\end{tabular}

Explanations and abbreviations as in Table 1

Phosphorus is essential for bone mineralization and development of structure of cellular membranes, nucleic acids and nucleotides, including adenosine triphosphate (Vitabase, 2009).

Potassium maintains electrolyte balance in humans (NTBG, 2009) and its presence in the food is very useful. Morgan (1999) indicated that reducing intake of sodium reduces the development of hypertension. The high $\mathrm{K}: \mathrm{Na}$ ratios of the soy powders imply that they could be useful in ameliorating sodium-related health risks among consumers (Arbeit et al., 1992; CIHFI, 2008). Magnesium (mg $100 \mathrm{~g}^{-1}$ ) contents ranged from 2.64 in $\mathrm{C}$ and $\mathrm{G}$ to 3.76 in $\mathrm{B}$; and iron $\left(\mathrm{mg} 100 \mathrm{~g}^{-1}\right)$ content from 1.00 in A to 5.09 in G. Magnesium is essential in enzyme system and helps maintain electrical potential in nerves (Ferrao et al., 1987). Fermenting in neutral medium for $16 \mathrm{~h}$ without changing the water (B) produced powder with highest calcium (440.44 mg $100 \mathrm{~g}^{-1}$ ) and magnesium $\left(3.76 \mathrm{mg} 100 \mathrm{~g}^{-1}\right)$ contents among the samples. The soybean powder produced from soybean fermented for $16 \mathrm{~h}$ with changing of $1 \%$ citric acid solution at $4 \mathrm{~h}$ intervals had the highest levels of most minerals among the various soybean powders.

Effect of Fermentation Time and Soaking Media on Phytochemical Composition of the Soybean Powders Table 3 shows phytochemical composition of the soybean powders/flours. Fermentation significantly $(p<0.05)$ reduced the phytochemical contents of the soy powders; and fermenting for $16 \mathrm{~h}$ was more effective than fermenting for $4 \mathrm{~h}$. Soy flour sample fermented for $16 \mathrm{~h}$ in neutral medium was more effective in reducing tannin and phenol contents of the flour samples than samples fermented in alkaline or acidic medium at the same time interval
(16 h). On the other hand, samples fermented in alkaline medium with $4 \mathrm{~h}$ fermentation in neutral medium was the most effective in retaining $\beta$ carotene content $\left(0.56 \mathrm{mg} 100 \mathrm{~g}^{-1}\right)$ of the soy flour but $16 \mathrm{~h}$ fermentation in neutral medium without changing the water, produced powder with the lowest phytate content (sample B with $2.11 \mathrm{mg} 100$ $\mathrm{g}^{-1}$ ). The soy powders were relatively high in phenol and phytate but low in tannin and $\beta$ carotene. Phenol content (mg $100 \mathrm{~g}^{-1}$ ) ranged from 5.63 in soy flour fermented for $4 \mathrm{~h}$ (A) to 3.61 in soy flour fermented for $16 \mathrm{~h}$ without changing the medium (B) while phytate content (mg $100 \mathrm{~g}^{-1}$ ) ranged from 6.75 in soy flour from soybean fermented for $4 \mathrm{~h}$ to 2.11 in soy flour from soybean fermented for $16 \mathrm{~h}$ in neutral medium with $4 \mathrm{~h}$ intermittent changing of medium. Fermenting for $16 \mathrm{~h}$ was better than fermenting $4 \mathrm{~h}$ soaking in detoxifying phytochemicals. Also, fermenting in neutral water was the best for detoxifying tannin and phenol. The $16 \mathrm{~h}$ fermentation without changing the water produced better soybean powder than the $16 \mathrm{~h}$ with intermittent changing the water.

Effect of Fermentation Time and Soaking Media
on Functional Properties of the Soybean Powders Table 4 shows the functional properties of the soybean powders. Water absorption capacity of the soy flours ranged from 36.7 in $\mathrm{C}$ (fermented $16 \mathrm{~h}$ in alkaline medium without changing of water) and $\mathrm{F}$ (fermented $16 \mathrm{~h}$ in alkaline medium with changing of water at $4 \mathrm{~h}$ intervals) to 23.3 in B (fermented 16 $\mathrm{h}$ in neutral medium without changing of water) and $\mathrm{E}$ (fermented $16 \mathrm{~h}$ in neutral medium with changing of water at $4 \mathrm{~h}$ intervals). The unfermented sample that was soaked for $4 \mathrm{~h}$ for easy dehulling had water absorption capacity of 30.0 , a value lower 
Table 3: Phytochemical composition of the soybean powders

\begin{tabular}{lcccc}
\hline Samples & Tannin $\left(\mathrm{mg} 100-\mathrm{g}^{-1}\right)$ & Phenol $\left(\mathrm{mg} 100-\mathrm{g}^{-1}\right)$ & $\beta$ - carotene $\left(\mathrm{mg} 100-\mathrm{g}^{-1}\right)$ & Phytate $\left(\mathrm{mg} 100-\mathrm{g}^{-1}\right)$ \\
\hline A & $1.50^{\mathrm{a}} \pm 0.04$ & $5.63^{\mathrm{a}} \pm 0.10$ & $0.56^{\mathrm{a}} \pm 0.00$ & $6.75^{\mathrm{a}} \pm 0.10$ \\
B & $1.19^{\mathrm{g}} \pm 0.02$ & $3.61^{\mathrm{g}} \pm 0.02$ & $0.24^{\mathrm{f}} \pm 0.01$ & $2.14^{\mathrm{f}} \pm 0.07$ \\
C & $1.39^{\mathrm{e}} \pm 0.03$ & $5.49^{\mathrm{b}} \pm 0.03$ & $0.47^{\mathrm{b}} \pm 0.00$ & $4.28^{\mathrm{e}} \pm 0.06$ \\
D & $1.46^{\mathrm{c}} \pm 0.00$ & $5.44^{\mathrm{c}} \pm 0.00$ & $0.44^{\mathrm{c}} \pm 0.01$ & $5.65^{\mathrm{b}} \pm 0.08$ \\
E & $1.48^{\mathrm{b}} \pm 0.01$ & $4.77^{\mathrm{e}} \pm 0.01$ & $0.39^{\mathrm{e}} \pm 0.00$ & $2.11^{\mathrm{g}} \pm 0.02$ \\
F & $1.33^{\mathrm{f}} \pm 0.03$ & $4.89^{\mathrm{d}} \pm 0.05$ & $0.11^{\mathrm{g}} \pm 0.02$ & $5.45^{\mathrm{c}} \pm 0.04$ \\
G & $1.42^{\mathrm{d}} \pm 0.05$ & $4.68^{\mathrm{f}} \pm 0.01$ & $0.43^{\mathrm{d}} \pm 0.00$ & $5.07^{\mathrm{d}} \pm 0.06$ \\
SEM & 0.002 & 0.251 & 0.002 & 0.002 \\
\hline
\end{tabular}

Explanations and abbreviations as in Tables 1 and 2

Table 4: Functional properties of the soybean powders

\begin{tabular}{lccc}
\hline Samples & Water absorption capacity & Least gelation concentration & Apparent viscosity \\
\hline A & $30.00^{\mathrm{b}} \pm 2.33$ & $19.33^{\mathrm{b}} \pm 1.32$ & $0.89^{\mathrm{b}} \pm 0.01$ \\
B & $23.30^{\mathrm{d}} \pm 2.22$ & $18.00^{\mathrm{c}} \pm 1.22$ & $0.97^{\mathrm{a}} \pm 0.01$ \\
C & $36.70^{\mathrm{a}} \pm 1.21$ & $16.33^{\mathrm{d}} \pm 1.01$ & $0.89^{\mathrm{b}} \pm 0.02$ \\
D & $30.00^{\mathrm{b}} \pm 1.19$ & $18.00^{\mathrm{c}} \pm 0.99$ & $0.93^{\mathrm{a}} \pm 0.03$ \\
E & $23.30^{\mathrm{d}} \pm 2.01$ & $16.67^{\mathrm{d}} \pm 1.23$ & $0.90^{\mathrm{ab}} \pm 0.01$ \\
F & $36.70^{\mathrm{a}} \pm 2.31$ & $18.00^{\mathrm{c}} \pm 1.11$ & $0.89^{\mathrm{b}} \pm 0.03$ \\
G & $26.70^{\mathrm{c}} \pm 1.12$ & $20.67^{\mathrm{a}} \pm 1.08$ & $0.90^{\mathrm{ab}} \pm 0.02$ \\
SEM & 3.81 & 0.48 & 0.08 \\
\hline
\end{tabular}

Explanations and abbreviations as in Tables 1,2 and 3

than the acid-fermented but higher than the alkalinefermented flours. Changing of media at intervals during the 16-h fermentation did not affect water absorption capacity of the flours. Also fermenting in alkaline and acidic media improved water absorption capacity of flours but this was higher in alkaline medium than in acidic medium. This could be due to hydrolysis of some insoluble polysaccharides and protein complexes during the adjusted alkaline and acidic $\mathrm{pH}$ conditions; and dissolution and leaching out of some neutral soluble fibre and protein in the neutral medium. Water absorption capacity of powder is the differences in weight of the powder before and after water absorption under sufficient water supply (Abbey and Ibeh, 1988). Imbibition of water is an important functional trait such as hydration, swelling, solubility and gelation in foods such as sausages, custards and dough (Adebowale et al., 2005). Depending on a protein side chain (number of charged and polar group), a protein may bind varying amount of water (Vaclavik and Christian, 2003). Water absorption capacity is also specific for each type of starch, and it depends on several factors such as amylaseamylopectin ratio, intra and inter molecular forces and size of granules (Rahman et al., 1999). The smaller the granules of the soybean powder, the higher the water absorption capacity of the powder (Singh et al., 2010). Water absorption capacity varies with protein source, composition, processing methods such as heating and alkali processing (Ikegwu et al., 2010). It is a function of ionic strength, $\mathrm{pH}$, temperature, size and shape of the protein molecules. The least gelation concentration ranged from 16.33 in $\mathrm{C}$ (fermented $16 \mathrm{~h}$ in alkaline medium without changing of water) to 2067 in G (fermented $16 \mathrm{~h}$ in acidic medium with changing of water at $4 \mathrm{~h}$ intervals). The unfermented sample had least gelation concentration of $19.33 \%$, a value significantly higher than every other sample except for $\mathrm{G}$. Least gelation concentration was highest in flour fermented at acidic $\mathrm{pH}$ with changing of water and in flour from unfermented soybean. Apparent viscosity was 0.89 in A (unfermented soy flour), $\mathrm{C}$ and F; 0.90 in E and G; 0.93 in D (fermented $16 \mathrm{~h}$ in acidic medium without changing of water) and 0.97 in B. Apparent viscosity was low in all the samples. Several changes may occur upon heating a starch-water system, including enormous swelling, increased viscosity, translucency and solubility. These changes are defined as gelatinization (Ikegwu et al., 2010). Huang et al. (2007), however, reported that amylopectin molecules are involved. Gelation of protein also occurs in flour and pastes and is very important for the preparation of puddings, jams and sauces that require thickening and jelling. Some kinds of proteins form gels through interactions with polysaccharide gelling agents such as starch and gelatin (Nunoo, 2009).

Effect of Fermentation Time and Soaking Media on Sensory Properties of the Soybean Powders Table 5 shows sensory scores for the powdered soybeans samples on a 9-point Hedonic scale. The sensory scores were high for all the seven samples and ranged from 7.28 for sample $\mathrm{G}$ for colour to 8.50 in overall acceptability. Soaking, fermentation, $\mathrm{pH}$ of fermenting medium and changing of medium during fermentation significantly $(p<0.05)$ affected sensory attributes of soy powders. Soy powder produced from $4 \mathrm{~h}$ soaking was the most acceptable by the sensory panelists. Fermenting for $16 \mathrm{~h}$ in alkaline medium with intervals of 4 hourly changing of the medium $(\mathrm{F})$ resulted to be the most acceptable colour (8.44) and flavour (8.44) while soaking for $4 \mathrm{~h}$ in neutral medium (A) resulted in the most acceptable mouth feel (8.44) and over-all acceptability (8.50). Thus, sample A was the most acceptable, but the best in quality was sample C. However, all the soy flours were acceptable to consumers; none of the sensory attributes was scored below 4.5 - the midmark of the 9-points hedonic scale used. 
Table 5: Sensory properties of the soybean powders

\begin{tabular}{lccccc}
\hline Samples & Colour & Texture & Flavour & Mouth feel & Overall acceptability \\
\hline A & $8.33^{\mathrm{b}} \pm 1.28$ & $8.22^{\mathrm{a}} \pm 0.94$ & $8.33^{\mathrm{b}} \pm 0.91$ & $8.44^{\mathrm{a}} \pm 0.98$ & $8.50^{\mathrm{a}} \pm 0.86$ \\
B & $7.78^{\mathrm{f}} \pm 1.52$ & $7.83^{\mathrm{d}} \pm 0.92$ & $7.61^{\mathrm{f}} \pm 1.75$ & $7.61^{\mathrm{f}} \pm 1.54$ & $7.56^{\mathrm{g}} \pm 1.65$ \\
C & $7.94^{\mathrm{e}} \pm 1.16$ & $7.50^{\mathrm{f}} \pm 1.30$ & $7.94^{\mathrm{d}} \pm 1.21$ & $7.22^{\mathrm{g}} \pm 2.18$ & $7.67^{\mathrm{f}} \pm 1.41$ \\
D & $8.17^{\mathrm{c}} \pm 0.99$ & $8.11^{\mathrm{b}} \pm 0.90$ & $7.72^{\mathrm{e}} \pm 1.84$ & $7.89^{\mathrm{d}} \pm 1.94$ & $8.22^{\mathrm{b}} \pm 0.73$ \\
E & $8.06^{\mathrm{d}} \pm 1.00$ & $8.22^{\mathrm{a}} \pm 0.73$ & $8.33^{\mathrm{b}} \pm 0.69$ & $8.06^{\mathrm{b}} \pm 1.00$ & $8.00^{\mathrm{c}} \pm 0.84$ \\
F & $8.44^{\mathrm{a}} \pm 0.62$ & $7.89^{\mathrm{c}} \pm 1.84$ & $8.44^{\mathrm{a}} \pm 0.71$ & $7.94^{\mathrm{c}} \pm 1.89$ & $7.94^{\mathrm{d}} \pm 1.92$ \\
G & $7.28^{\mathrm{g}} \pm 1.93$ & $7.56^{\mathrm{e}} \pm 1.04$ & $8.17^{\mathrm{fc}} \pm 0.79$ & $7.67^{\mathrm{e}} \pm 1.19$ & $7.89^{\mathrm{e}} \pm 1.08$ \\
SEM & 0.29 & 0.27 & 0.27 & 0.37 & 0.30 \\
\hline
\end{tabular}

Footnote as with Tables 1-4

\section{CONCLUSION}

Fermentation time and $\mathrm{pH}$ of fermentation media affected nutrient composition, functional and sensory properties of powdered soybeans. The soybean powders were rich in both macro and micro nutrients, had good functional properties and were acceptable to the sensory panelists. Fermentation reduced phytochemical composition of the soy powders; and fermenting in neutral medium for $16 \mathrm{~h}$ produced the best soy powder. Fermenting soybean seeds in neutral medium for soy powder production is recommended.

\section{REFERENCES}

AACC (2000). Method 46-30; Approved Methods of American Association of Cereal Chemists, $\left(10^{\text {th }} \mathrm{ed}.\right)$, AACC International, St. Paul, MN

Abbey B.W. and Ibeh S.O. (1988). Functional properties of raw and heat processed cowpea (Vigna unguiculata, walp) flour. J. Food Sci., 53 (6), 1775-1791

Adebowale K.O., Olu-Owolabi B.I., Olawumi E.K. and Lawal O.S. (2005). Functional properties of native, physically and chemically modified breadfruit (Artocarpus altilis) starch. Ind. Crop Prod., 21, 343-351

Akande K.E. and Fabiyi E.F. (2010). Effect of processing methods on some anti-nutritional factors in legume seeds for poultry feeding. Int. J. Poult. Sci., 9, 996-1000

AOAC (2000). Association of Official Analytical Chemists: Official Method of Analytical Chemists. $18^{\text {th }}$ ed. Washington D.C pp. $18-62$

Arbeit M.L., Nicklas T.A. and Berenson G.S. (1992). Considerations of dietary sodium/potassium/energy ratios of selected foods. J. Am. College Nutr., 11 (2), 210-22

CIHFI (2008). Wichita USA. The Center for the Improvement of Human Functioning International (CIHFI). http// biocenterlab.org/tests/urine/kna.shtml, Accessed 14/08/ 2010

De Villota E.D.D., Ruiz C.M.T., Rubio J.J. and De Andre's S. (1981). Equality of the in vivo and in intro oxygen binding capacity of heamoglobin in patients with severe respiratory disease. Brit. J. Anaesth., 53 (12), 13251328. DOI: $10.10 .93 / \mathrm{bja} / 53.12$. 1325PMID:7317251

FAO (2009). Technology of products from soybeans. FAO Agricultural Science Bulletin 2. Rome, Italy

Ferrao J.E.M., Ferrao A.M.B.C. and Anatures A.M.G. (1987). Garcia deorta, serieda estudes. Agronomicos, 14 (1-2), 35-39

Giampietrol P.G., Bruno G.F., Casati A.G., Brunneti E.S., Spardoni C.L. and Galli E.D. (2004). Soy protein in long term feeding. J. Pediatric Endocrinol. Metab., 5, 240-248

Huang J., Schols H.A., van Soest J.J.G., Jin Z., Sulmann E. and Voragen A.G.J. (2007). Physicochemical properties and amylopectin chain profiles of cowpea, chickpea and yellow pea starches. Food Chem., 101 (4), 1338-1345

Ikegwu O.J., Okechikwu P.E. and Ekumankana E.O. (2010). Physico-chemical and pasting characteristics of flour and starch from Brachystegia eurycoma seed. J. Food Technol., 8 (2), 58-66
Mellgaard M., Civille C.V. and Carr B.T. (1999). Sensory Valuation Techniques, $3^{\text {rd }}$ ed., CRC Press Inc. Boca Raton

Morgan T.O. (1999). Restriction of salt intake is needed to ameliorate the cardiovascular disease epidemic. The Medical J. Aust., 170, 176-178

National Academy of Sciences (2004). Proceedings of the National Academy of Sciences, 101 (52), 118-124

NTBG (2009). Hunger initiatives, Breadcfruit Institute. National Tropical Botanical Garden (NTBG). http:// wwwntbg.org/breadfruit/breadfruit. Accessed 26/08/2010

Nunoo P. (2009). Pasting of G-Irradiated Proteins from Vigna subterranean in Native Starch Models and the Surface Functional Properties of the Proteins. M.Sc. Thesis Submitted to the Department of Food Science \& Technology, Kwame Nkrumah University of Science \& Technology, Kumasi, Ghana, p. 72

Prestamo G.D., Lesmes M.F., Otero I.F. and Arroyo G.G. (2000). Soybean vegetable protein (Tofu preserved with high pressure). J. Agric. Food Chem., 48 (7), 2943-7

Price M.L. and Butler, L. G. (1977). A spectophotometric method of determination of tannin content of sorghum grain. J. Agric. Food Chem. 25 (6), 1268-1273

https://pubs.acs.org Prodanov M.A., Vierra I.H. and Vidal V.A. (2004). Influence of soaking and cooking on thiamin, riboflavin and niacin contents in legumes. Food Chem., 84, 271-277

Rahman M.A., Nahar N., Jabbar M.A. and Mosihuzzaman M. (1999). Variation of carbohydrate composition of two forms of fruit from jack tree (Arthocarpus heterophyllus L.) with different maturity and climatic conditions. Food Chem., 65, 91-97

Roesler R., Malta G.M., Carrasco L.C. and Pastore, G. (2006). Evaluation of the antioxidant properties of the Brazilian cerrado fruit Annona crassiflora (Araticum). J. Food Sci., 71 (2), C102-C107.

Singh S., Singh N. and MacRitchie F. (2010). Relationship of polymeric proteins with pasting, gel dynamic and dough empirical-rheology in different Indian Wheat varieties. Food Hydrocolloids, 25 (1), 19-24

Singh S.R., Rachie K.O. and Dashiell K.E. (2000). Soybean for the Tropics Research Production and Utilization. John Wiley \& Sons Ltd., pp. 1-5, 167-170

Singleton V.L., Orthofer R. and Lamuela-Raventos R.M. (1999). Analysis of Total phenols and other oxidation substrates and antioxidants by means of Folin Ciocalteu reagent. Method in Ezymology, 299, 152-178. http://dx.doi.org/10.1016/S0076-6879(99)99017-1

Sneller C.H. (2003). Impact of transgenic genotypes and subdivision on diversity within elite North America soybean germplasm. Yong Wright, pp. 117-208

Ugwuona F.U. (2009). Chemical and sensory evaluation of soy-fortified cassava wheat biscuit. Agro-Sci., 8 (1), 55-59

Vaclavik V.A. and Christian E.W. (2003). Essentials of Food Science ( $2^{\text {nd }}$ ed.), Elizabeth Christian Publishing, England, Part III, Chapter 8

Vitabase C. (2009). Vitamin and health guide. [http://www. vitamins-upplements.org/dietary-minerals/phosphorus.php] 